\title{
The Effect of Implementing Self-Assessment System on Tax Compliance for Small-Medium Enterprises (SMEs), Lembang, West Bandung District
}

\author{
Victor C. Sinaga ${ }^{1}$, Judith T. Gallena Sinaga ${ }^{2}$ \\ Universitas Advent Indonesia \\ victor.sinaga@unai.edu
}

\begin{abstract}
Small-Medium Enterprises (SMEs) play a vital role in economic development of Indonesia. To support its economic development, the government is obliged to generate revenue. In order to generate more revenue, Indonesian government implemented self- assessment system in compliance with tax obligations. Most of the SMEs are compliant while some are not that aware of it because of lack of socialization. The aim of this study is to comprehend the effect of implementing self-assessment system on tax compliance.

This study focused on SMEs in Lembang, West Java, Indonesia. It was exploratory research based on data were gathered from West Java Regency Office. Questionnaires were distributed to 70 (based on Slovin formula) respondents from the total population of 244.

The result showed that the correlation of implementation of self-assessment system on tax compliance is weak, thus, the findings showed that implementation of self-assessment system has no significant influence on tax compliance.

Implementation of self-assessment system has no significant influence on tax compliance. There are several reasons for this, such as, most of the people around the district of Lembang are not yet fully aware about its implementation. Also, it is not well socialized by the tax authorities from the Revenue Offices. It lacks personnel to do the socialization. The stated reasons were affirmed during the interview with the Head of SMEs located in West Bandung Regency. Implementation of the Self - Assessment System is worth to grab by SMEs in the district of Lembang, Bandung, Indonesia. It is highly recommended to socialize again the implementation and assign personnel that can extend time and effort to socialization.
\end{abstract}

Keywords: Smes, Revenue, Self-Assessment, Socialization, Compliance

\section{INTRODUCTION}

Indonesia continuously improves and develops its infrastructure in all sectors, be it in economics, politics, technology, and industry. In order to materialize these improvements and developments, Indonesian government need funds that can support it. The government usually relies on the funds generated from taxes. Taxes are the main source of fund for one's country to sustain its economic activities. Tax reforms are being implemented to boost the taxpayers to be compliant in tax obligations. One of the tax reforms was the implementation of Self- 
Assessment System. Aside from the other taxpayers such as corporate and individual, smallmedium enterprises are also subject to this tax reform. Economic activities are dominated by small - medium sized enterprises (SMEs). The SMEs contribution to economic development of Indonesia is to pay taxes religiously. Based on the data gathered from Bureau of Statistics (Badan Pusat Statistik), it is known that less than 20 million taxpayers were listed in SMEs. Taxes collected from SMEs taxpayers were relatively small if compared to what it is supposed to be. Taxpayers are sometimes negligent on their tax obligations, non-compliance to rules and regulations or even intentionally not fulfill its duties to the government.

Indonesian government anticipated to maximize the collection of taxes from SMEs. In order to maximize the collection of taxes, SMEs (taxpayers) were given the chance to pay taxes on its own awareness. It was socialized that taxes can be paid voluntarily by the SMEs (taxpayers) through Self-Assessment System. Under the self-assessment system, the taxpayer, rather than the tax authorities, is primarily responsible for the assessment of tax liability; and the taxpayer is required to calculate gross income, allowable deductions and taxable income. In selfassessment, the taxpayer also calculates the actual tax due and pays the tax when submitting the returns (Veerinderjeet, 1997). Through this system, SMEs (taxpayers) were expected to comply with in paying taxes. The individual taxpayer will be responsible for determining the amount of tax that he or she is liable to pay. The individual taxpayer will be responsible for determining the amount of tax that he or she is liable to pay; that amount will have to be paid without an assessment (Jones, 1996).

Taxpayers were given the full trust to calculate, deposit and report obligations on tax as required by tax authorities. This study talks about the implementation of self-assessment system on tax compliance. Thus, the objective of this study is to explain how far the taxpayers (SMEs) comply with the tax rules and regulations.

\section{LITERATURE REVIEW}

Small and Medium Enterprises (SMEs) Overview: Indonesia Perspective. Small medium enterprises, in Indonesia, are increasing in number. Micro, small and medium enterprises (MSMEs) is known as Usaha Mikro, Kecil dan Menengah (UMKM). SMEs provide a lot of benefits for the owner and the nation's economy. According to Kushnir, et al (2010), on average, there are 31 MSMEs per 1,000 people across the 132 economies covered. The five countries with the highest formal MSME density are as follows: Brunei Darussalam (122), 
Indonesia (100), Paraguay (95), the Czech Republic (85), and Ecuador (84). In Republic Act 2008 No 20 about MSME (www.bi.go.id/), it is stated that,

1. Micro is a productive enterprise owned by the individual and / or individual business entities which meet the Micro criteria as stipulated in this Law.

2. Small Business have productive economic activity, which is carried out by an individual or business entity that is not a subsidiary or branch of companies owned, controlled, or be part of either directly or indirectly from medium enterprises or large businesses that meet the criteria of small business as defined in this Act.

3. Medium Enterprises have productive economic activities that stand alone, carried out by individuals or a business entity that is not a subsidiary or branches of companies owned, controlled, or be part of either directly or indirectly with small business or large businesses with total net assets or annual sales revenue as stipulated in the Law.

In addition to this, the criteria cited in Republic Act 2008 No. 20 is as follows:

1. Criteria for Micro are as follows:

1) have a maximum net worth Rp50,000,000.00 (about U\$3,500) excluding land and buildings; or

2) has annual sales results Rp300,000,000.00 (about U\$21,000).

2. Criteria for Small Business are as follows:

1) have a net worth of more than Rp50,000,000.00 (about U\$3,500) up to at most 500,000,000.00 (about U\$ 35,000) excluding land and buildings; or

2) has an annual sales of more than Rp300,000,000.00 (about U\$ 21,000) up with most Rp2.500.000.000,00 (about U\$ 175,000)

3. Criteria for Medium Enterprises are as follows:

1) have a net worth of more than Rp500,000,000.00 (about U\$35,000) up to at most Rp10,000,000,000.00 (about U\$ 700,000) excluding land and buildings; or

2) has an annual sales of more than Rp2.500.000.000,00 (about U\$ 175,000) up with the most Rp50.000.000.000,00 (about U\$ 3,500,000).

4. The criteria referred to in paragraph (1) letter $a$, letter $b$, and paragraph (2) letters $a, b$, and paragraph (3) letters a, b nominal value can be changed in accordance with economic development is governed by President Regulation."

Micro, small, or medium enterprises help uplift the economy of one's nation. It helps the nation in improving the livelihood of the people. Small businesses greatly contribute to the economic development of a country (Abor and Quartey, 2010; Halabi et al., 2010). Their contribution is 
gauged in terms of job creation, income generation and poverty reduction (Agyei-Mensah, 2011).

The establishments of SMEs help boost the economy individuals, and also SMEs creates job thus reduces unemployment in the country.

Self-Assessment System. Self-Assessment System is a voluntary way of assessing taxpayer's own tax obligations to government. Self-assessment is a more straightforward way of calculating and paying tax (Anonymous, 1995). Self-Assessment (SA) system of tax administration has been gaining wide acceptability globally (Saad, 2014). This method of paying taxes allows each taxpayer to calculate voluntarily the taxes to be paid. Payments received will probably add the revenue of the government. The introduction of the selfassessment system is a broad attempt by the Government to ensure that taxation laws are complied with, while decreasing the incidence of delinquency in complying with the requirement to submit tax returns (Fan \& Sin, 1999). There are some reasons why taxpayers become delinquent to pay taxes thereby not complying with tax rules and regulations.

Self-assessment system has been practiced long time ago. Self assessment is a system of tax administration first introduced in 1913 by United States (Loo, 2006). SAS has already been taking shape in developed countries like New Zealand, UK and Australia (James \& Alley, 2002) and in developing nations such as Malaysia, Bangladesh, Indonesia and Pakistan (Sapiei \& Kasipillai, 2013). As mentioned, Indonesia also emphasizes that taxpayers must submit income tax return as a proof that taxpayers are willing to report and pay required taxes.

Indonesia implemented this system as a way to collect taxes and to increase government revenue. Many taxpayers (SMEs) participated in this kind of system in order to help the government generate revenue. SMEs that are aware of paying tax will surely comply with tax rules and regulations, while those who are not well-informed about the system would probably forget to follow the rules. You have to carefully read the most recent available literature with a view to identify specific gaps, inconsistencies and/or controversies that may form the basis of your own research. Always show that you have considered an issue from a number of angles and that you are aware of the arguments for and against a specific point of view. Many researchers in services marketing, for example, use the SERVQUAL measurement scale without considering existing criticisms against it.

Self-assessment System Implementation. According to Okello (2014), following are the facts about self-assessment system: 
1. The self-assessment system accepts the reality that no tax administration has, or ever will have, sufficient resources to determine the correct liability of every taxpayer. It also recognizes that taxpayers themselves - with appropriate assistance from the tax department - are in the best position to determine their tax liabilities, given that they have first-hand knowledge of their business affairs and financial transactions, and have ready access to underlying accounting records.

2. Self-assessment is based on the idea of voluntary compliance. In a self-assessment system, taxpayers calculate and pay their own taxes without the intervention of a tax official. If this is not done appropriately and within the prescribed timeframes, the tax administration detects this failure and takes appropriate enforcement action, including applying the penalties provided for in the law. Tax administrations generally accept tax returns at face value (i.e. not subjected to technical scrutiny) at the time of filing, at which time the tax due is paid. Some simple checks may be performed; however, the focus is to ensure arithmetical accuracy and that the taxpayer has completed the appropriate items on the tax return form.

3. Self-assessment systems require far less information and supporting documents from taxpayers when returns are filed. Business taxpayers must, however, keep records explaining all transactions relevant for tax purposes, including sales and expense invoices and receipts, wages records, cash register tapes, bank account statements, and details of debtors, creditors, trading stock and depreciable assets. Generally, it is permissible for a taxpayer to issue and store records in either paper or electronic form. The law typically provides for penalties for not maintaining the required records and for not keeping them for the required period, generally around five years for business taxpayers.

4. The role of the tax administration under self-assessment is first and foremost to assist the taxpayers to understand their rights and obligations under the law. Given that more responsibility is placed on taxpayers to correctly interpret the law, greater attention is given to educating and assisting taxpayers in understanding the law's requirements. The tax administration also makes it easy and as least costly as possible for taxpayers to meet their obligations. Self-assessment demands that tax administrations adopt a service-oriented attitude towards taxpayers.

5. The emphasis under a self-assessment system shifts the verification process from preto a post-filing basis. The tax administration relies more on post-filing controls such as 
risk-based audits, collection enforcement measures, and prosecution of tax evaders. Tax administrations operating self-assessment systems adopt targeted verification approaches, (e.g., through information sharing, data matching, and risk-based desk and field audits) to verify the information contained in tax returns. In this way, the tax administration's limited.

The above mentioned facts proved that self-assessment system encourages the taxpayers to pay their obligations to the government.

Tax Compliance. Government has stipulated rules about paying taxes that is due to every taxpayer. Compliance with these rules of every taxpayer is inevitable wherein taxes are not to be avoided or evaded but it should be complied with law abiding citizen (taxpayers). Tax compliance has always been an area of concern to policy makers, tax administrators and society in general (Isa,2014). Tax compliance is likely to become a more significant aspect of tax policy as most of the old problems remain and new considerations are raised by developments such as selfassessment, the emergence of the global economy and electronic commerce (James $\&$ Alley, 2002). Despite of some problems encountered in paying taxes, still, obligations to pay taxes should not be neglected. In this era of technology, it is more efficient to pay taxes because queuing is no longer a waste of time but then there should be a proper socialization of every development. Tax compliance mainly affects revenue collection and the ability of the government to achieve its fiscal and social goals (Tan and Sawyer, 2003, p. 1). Tax compliance is an issue hassling both developed and developing countries, and one of the possible determinant of tax noncompliance is complexity of tax system (Gambol, et al., 2014). Nowadays, the complexity of tax system has decreased because the government has adopted ways to make it less complex and that is through self-assessment system.

Isa (2014) said that "Measures to improve compliance include providing excellent taxpayer services that generate better long-term outcomes such as higher tax collection and a reduction in the tax gap. The aim of tax reform in many countries is to achieve higher voluntary compliance and one way to achieve this is by introducing a self-assessment system (SAS). Tax compliance is based on trust or power of authorities. Where tax compliace is based on trust, it becomes voluntary tax compliance, but if tax compliance is based on power, it is called enforced compliance (Kirchler, Hoelzl, \& Wahl, 2008; Kirchler, Hofmann, \& Gangl, 2012; Kogler et al., 2013; Wahl, Kastlunger, \& Kirchler, 2010). Thus, SA is based on the principles of voluntary tax compliance. Trust is the key word to comply the obligation on taxes. Although 
it pays to have trust in order to be compliant, taxpayers must still have to be a law abiding citizen.

Okello (2014) "The most cost effective systems of collecting taxes are those that induce the vast majority of taxpayers to meet their tax obligations voluntarily, leaving tax officials to concentrate their efforts on those taxpayers who do not comply. Taxpayers are more likely to comply voluntarily when the tax administration: (1) adopts a service-oriented attitude toward taxpayers, and educates and assists them in meeting their obligations; (2) creates strong deterrents to non-compliance through effective audit programs and consistent use of penalties; and (3) is transparent and seen by the public to be honest, fair, and even-handed in its administration of the tax laws. Experience shows that voluntary compliance is best achieved through a system of self-assessment." Implementing such system that is effective for tax collections will surely generate huge tax revenues for the government. Also, a service-oriented a The Effect of Self-Assessment System on Tax Compliance. Self-assessment has implications for compliance and a movement towards a greater element of self-assessment has been taking place in countries such as New Zealand (Inland Revenue Department, 1995), the UK (James, 1995) and Australia (Sandford \& Wallschutzky, 1994). Under self-assessment it is the responsibility of the taxpayer rather than the revenue authority to calculate the relevant tax liability and to ensure that the requirements regarding payment and so on are met (Barr, James \& Prest, 1977).

Self-assessment system has been implemented in various countries. This system benefits both the taxpayer and revenue authority. For taxpayer, it calculates voluntarily the taxes to be paid; while for tax authority, it lessens some work to be done. ttitude help boost the willingness of every taxpayer to comply with its tax obligations.

Based on the above statement, the following hypothesis is being developed:

Ha: Implementation of self-assessment system affects tax compliance.

H0: Implementation of self-assessment system has no effect on tax compliance.

\section{METHODS}

Methods section describes the steps followed in the execution of the study and also provides a brief justification for the research methods used (Perry et al., 2003:661). It should contain enough detail to enable the reader to evaluate the appropriateness of your methods and the reliability and validity of your findings. Furthermore, the information should enable 
experienced researchers to replicate your study (American Psychological Association, 2001:17).

1. The methodology section typically has the following sub-sections:

2. Sampling (description of target population, research context and units of analysis; sampling; and respondent profile)

3. Data collection

4. Measures (Alternatively: Measurement)

\section{RESULTS}

This study focused on SMEs in Lembang, West Java, Indonesia. It was exploratory research based on data were gathered from West Java Regency Office. Questionnaires were distributed to 70 (based on Slovin formula) respondents from the total population of 244. Likert scale was used for its measurement; as such 4 for Strongly Agree, 3 for Agree, 2 for Disagree, and 1 for Strongly Disagree. A 5\% significance level was used to test the significance of implementation of self-assessment system on tax compliance. In this study, Implementation of Self-assessment System is the independent variable and Tax Compliance is the dependent variable.

\section{DISCUSSION}

The awareness of taxpayer (SMEs) in fulfilling tax obligations and the role of the tax authorities in the process of self-assessment system. Following are the results of the questionnaire for variable the implementation of the self-assessment system:

\section{Table 1. Questionaire No.1 - Self-assessment System is an independent system to collect taxes in Indonesia}

\begin{tabular}{lcc}
\hline \multicolumn{1}{c}{ Scale } & Frequency & Percentage \\
\hline Strongly Disagree & 0 & 0 \\
Disagree & 13 & 19 \\
Agree & 40 & 57 \\
Strongly Agree & 17 & 24 \\
Total & 70 & 100 \\
\hline
\end{tabular}

Table 1 showed that there were 40 respondents (57\%) agreed that taxpayers were aware that the self-assessment system is being implemented in Indonesia. There were some respondents (SMEs) that are not aware of this system. The implementation of this system will definitely 
increase government revenue from taxes. Despite of the fact that majorities of the respondent were aware of it, still the 13 respondents should have to follow this system as a sign of being a law abiding citizen. SMEs must support the government in generating revenue.

Table 2. Questionaire No.2 - Self-assessment system gives the taxpayer the trust to voluntarily calculate, pay, and report its own taxes.

\begin{tabular}{lcc}
\hline \multicolumn{1}{c}{ Scale } & Frequency & Percentage \\
\hline Strongly Disagree & 1 & 1 \\
Disagree & 14 & 20 \\
Agree & 37 & 52 \\
Strongly Agree & 18 & 27 \\
Total & 70 & 100 \\
\hline
\end{tabular}

Table 2 showed that there were 37 respondents (52\%) agreed that taxpayers are aware that the self-assessment system is being implemented in Indonesia, yet there were 14 and 1 respondent who disagreed and strongly disagreed respectively. Respondents' disagreement was due to being reluctant to calculate and pay taxes. The system gave the taxpayers the opportunity to voluntarily calculate, pay, and report it taxes. Taxpayers were trusted to make the computation and report by the result of what was calculated. In a self-assessment system, taxpayers calculate and pay their own taxes without the intervention of a tax official.

\section{Table 3. Questionaire No.3 - Through Self-assessment System, I become more responsible to process my taxes.}

\begin{tabular}{ccc}
\hline Scale & Frequency & Percentage \\
\hline Strongly Disagree & 2 & 3 \\
Disagree & 3 & 4 \\
Agree & 50 & 71 \\
Strongly Agree & 15 & 21 \\
Total & 70 & 100 \\
\hline
\end{tabular}

Table 3 showed that majority of the respondents (50) agreed that self-assessment taught the SMEs to be more responsible in processing taxes. Being responsible is being concern with the welfare of the country. There were 2 respondents who strongly disagreed and 3 respondents expressed disagreement. These respondents have no interest in fostering the welfare of the government. Taxpayers are more likely to comply voluntarily when the tax administration creates strong deterrents to non-compliance through effective audit programs and consistent 
use of penalties; and is transparent and seen by the public to be honest, fair, and even-handed in its administration of the tax laws.

Table 4. Questionaire No.4 - Government's service support self-assessment system that helps the taxpayers

\begin{tabular}{lcc}
\hline \multicolumn{1}{c}{ Scale } & Frequency & Percentage \\
\hline Strongly Disagree & 5 & 7 \\
Disagree & 12 & 17 \\
Agree & 45 & 65 \\
Strongly Agree & 8 & 11 \\
Total & 70 & 100 \\
\hline
\end{tabular}

Table 4 showed that majority of the respondents (45) agreed that government's service support helps the taxpayers. Government made it easier to file taxes to every SME yet there were respondents who disagreed (12) and strongly disagreed (5) about government's service support. These respondents felt that government's service is not that helpful to taxpayers. Taxpayers are more likely to comply voluntarily when the tax administration adopts a service-oriented attitude toward taxpayers, and educates and assists them in meeting their obligations.

Table 5. Questionaire No.5 - Socialization of Self-assessment System is doing good.

\begin{tabular}{lcc}
\hline \multicolumn{1}{c}{ Scale } & Frequency & Percentage \\
\hline Strongly Disagree & 3 & 4 \\
Disagree & 22 & 31 \\
Agree & 37 & 53 \\
Strongly Agree & 8 & 11 \\
Total & 70 & 100 \\
\hline
\end{tabular}

Table 5 showed that majority agreed (37) that self-assessment system was socialized clearly in every tax payers. There were 3 respondents who disagreed and 22 respondents disagreed that socialization was not done accordingly.

Table 6. Coefficient of Correlation (Self-Assessment on Tax Compliance) Model Summary

\begin{tabular}{|c|c|c|c|c|c|}
\hline Mode & $\mathrm{R}$ & $\begin{array}{c}\mathrm{R} \\
\text { Square }\end{array}$ & $\begin{array}{l}\text { Adjusted } \\
\text { Square }\end{array}$ & $\mathrm{R}$ & $\begin{array}{l}\text { Std. Error of the } \\
\text { Estimate }\end{array}$ \\
\hline 1 & $.192^{\mathrm{a}}$ & .037 & & .023 & 4.29977 \\
\hline
\end{tabular}

a. Predictors: (Constant). Implementation_Self_Assessment_System 
Table 7 shows that the coefficient of correlation $(r)$ is +0.192 , which means that the correlation of self-assessment system with tax compliance is very weak. Meanwhile, the coefficient of determination is 0.037 or $3.7 \%$, it shows that the contribution of self-assessment system to tax compliance is only $3.7 \%$ and the remaining percentage is contributed by others factors.

Table 7. Significance test (Self-Assessment on Tax Compliance) Coefficients ${ }^{\mathrm{a}}$

\begin{tabular}{|c|c|c|c|c|c|}
\hline \multirow[t]{2}{*}{ Model } & \multicolumn{2}{|c|}{$\begin{array}{l}\text { Unstandardized } \\
\text { Coefficients }\end{array}$} & \multirow{2}{*}{$\begin{array}{c}\text { Standardized } \\
\text { Coefficients } \\
\text { Beta }\end{array}$} & \multirow[t]{2}{*}{$\mathrm{T}$} & \multirow[t]{2}{*}{ g. } \\
\hline & B & $\begin{array}{l}\text { Std. } \\
\text { Error }\end{array}$ & & & \\
\hline (Constant) & 23.721 & 3.10 & & 7.634 & .000 \\
\hline Implementation_of & & 7 & & 1.616 & .111 \\
\hline 1 Self_Assessment & .336 & & .192 & & \\
\hline System & & .208 & & & \\
\hline
\end{tabular}

a. Dependent Variable:Tax Compliance

Table 7 shows that the result of significance test result is .111 which is greater than significance level of 0.05 . This indicates that $\mathrm{Ha}$ is rejected, which means that implementation of selfassessment system has no significant influence on tax compliance. There are several reasons for this, such as, most of the people around the district of Lembang are not yet fully aware about its implementation. Also, it is not well socialized by the tax authorities from the Revenue Offices. It lacks personnel to do the socialization. The stated reasons were affirmed during the interview with the Head of SMEs located in West Bandung Regency.

\section{Conclusion}

Implementation of the Self - Assessment System is worth to grab by SMEs in the district of Lembang, Bandung, Indonesia. The self-assessment system accepts the reality that no tax administration has, or ever will have, sufficient resources to determine the correct liability of every taxpayer. Self-assessment is based on the idea of voluntary compliance. Selfassessment systems require far less information and supporting documents from taxpayers when returns are filed. The role of the tax administration under self-assessment is first and foremost to assist the taxpayers to understand their rights and obligations under the law. The emphasis under a self-assessment system shifts the verification process from pre- to a post-filing basis.

Its implementation will give the taxpayer to voluntarily fulfill or comply its obligation with the government. Tax compliance will eventually help the government to increase its revenue. 
On the other hand, the result of this study showed that the implementation of self-assessment system has no significant influence on tax compliance. One of the reasons of not being significant is that, the system is not properly socialized to the SMEs thus making the SMEs not fully aware with the system. Since some SMEs were not aware about the implementation of this system, proper attention must be given and proper dissemination of tax information to SMEs in Lembang, West Bandung District.

\section{Recommendation}

Based on the facts that the implementation of self-assessment system is not fully implemented yet, although there are few of them understand the importance of its implementation on tax compliance. It is highly recommended to socialize again the implementation and assign personnel that can extend time and effort to socialization.

\section{REFERENCES}

Anonymous. (1995), Self-assessment: A clearer tax system. Management Accounting. ABI/INFORM Collection, p. 59.

Barr, N.A., James, S.R., \& Prest, A.R. (1977). Self-Assessment for Income Tax. London, Heinemann.

Fan, L.K. and Sin, C.L. (1999). Unveiling the self-assessment tax system. The New Straits Times Press (M) Berhad,Kuala Lumpur, page 5.

Gambo, E. J., Mas'ud, A., Nasidi, M., \& Oyewole, S. (2014). Tas Complexity and Tax Compliance in African Self-Assessment Environment, International Journal of Management Research \& Review, Volume 4, Iss. 5, Article No. 5, pp. 575-582.

Inland Revenue Department. (1995, April). Taxpayer Compliance Standards and Penalties2: Detailed Proposals and Draft Legislation: A Government Discussion Document. Wellington, New Zealand.

Isa, K. (2014). Tax complexities in the Malaysian corporate tax system: minimise to maximise. International Journal of Law and Management, Vol. 56 No. 1, pp. 50-65. DOI 10.1108/IJLMA-08-2013-0036.

James, S., \& Alley C. (2002). Tax compliance, self-assessment and tax administration pp.27-42.

James, S. (1995). Self-Assessment and the UK Tax System, London, Research Board of the Institute of Chartered Accountants in England and Wales.

Jones, H. (1996). Shifting the burden of tax compliance. Consumer Policy Review ; London Vol. 6, Iss. 2, (Mar/Apr 1996): 50. 
Kirchler E, Hoelzl E, Wahl I. (2008). Enforced versus voluntary tax compliance: The "slippery slope" framework, Journal of Economic Psychology, Vol. 29 (2), pp. 210225.

Kirchler E, Hofmann E, Gangl K. (2012). From Mistrusting Taxpayers to Trusting Citizens Empirical Evidence and Further Development of the Slippery Slope Framework. Vol. 88 (4), pp. 125.

Kogler C, Batrancea L, Nichita A, Pantya J, Belianin A, Kirchler E. (2013). Trust and power as determinants of tax compliance: Testing the assumptions of the slippery slope framework in Austria, Hungary, Romania and Russia, Journal of Economic Psychology, Vol. 34, pp. 169-180.

Loo, E.C. (2011). The influence of the introduction of self assessment on compliance behaviour of individual taxpayers in Malaysia.

Okello, A. (2014). Managing Income Tax Compliance through Self-Assessment. International Monetary Fund, pp. 1-37.

Saad, N. (2014). Tax Knowledge, Tax Complexity and Tax Compliance: Taxpayers' View. Procedia- Social and Behavioral Sciences 2014; 109: 1069-1075.

Sandford, C., \& Wallschutzkty, I.G. (1994). Self-Assessment of Income Tax: Lessons from Australia. British Tax Review, No. 3.

Sapiei, N.S. \& Kasipillai, J. (2013). Impacts of the Self-Assessment System for Corporate Taxpayers. American Journal of Economics; Vol. 3 (2), pp. 75- 81.

Tan, L.M. and Sawyer, A.J. (2003). A synopsis of taxpayer compliance studies - overseas vis-a' 'vis New Zealand, New Zealand Journal of Taxation Law and Policy, Vol. 9, pp. $1-24$.

Veerinderjeet, S. (1997). Self-assessment tax system will cut administrative costs. Business Times ; Kuala Lumpur 21 Mar 1997: 05. 